\title{
KEKERASAN SEKSUAL PADA ANAK: PEMBUKTIAN OLEH TENAGA MEDIS (SEXUAL VIOLENCE AGAINST CHILDREN: EVIDENCE BY MEDICAL PROFESSIONAL)
}

\author{
$\underline{\text { Nurul Aida Fathya }}^{1}$, Elly Noer Rochmah ${ }^{2}$, Faris Fauzan Zain ${ }^{3}$ \\ ${ }^{1}$ Laboratorium Ilmu Kedokteran Forensik dan Medikolegal, Fakultas Kedokteran \\ Universitas Jenderal Achmad Yani \\ ${ }^{2}$ Departemen Ilmu Kesehatan Anak, Fakultas Kedokteran Universitas Jenderal Achmad Yani \\ ${ }^{3}$ Program Studi Kedokteran, Fakultas Kedokteran Universitas Jenderal Achmad Yani \\ Email korespondensi : nurul.aida.fathya@gmail.com
}

\begin{abstract}
ABSTRAK
Kasus kekerasan seksual pada anak merupakan fenomena gunung es, karena korban umumnya enggan melapor. Bentuk kekerasan seksual pada anak meliputi tindakan menyentuh atau mencium organ seksual, memperlihatkan pornografi, menunjukkan alat kelamin, seks oral, masturbasi, seks anal, hingga persetubuhan. Kekerasan seksual pada anak termasuk ke dalam tindak pidana, dan untuk pembuktiannya dibutuhkan data medis atas korban. Bukti adanya kekerasan adalah luka atau bekas luka pada tubuh korban. Permasalahan pembuktian tanda kekerasan muncul ketika korban tidak segera melapor, dan dilakukan pemeriksaan medis. Penelitian ini bertujuan untuk mengetahui pola perlukaan korban kekerasan seksual pada anak. Metode penelitian ini bersifat deskriptif dengan data penelitian yang diambil dari rekam medis korban. Penelitian dilakukan di Rumah Sakit Umum Pusat Dr. Hasan Sadikin Bandung, sebagai rumah sakit rujukan utama Provinsi Jawa Barat. Hasil penelitian menunjukkan bahwa terdapat 71 kasus selama periode 2012-2017 dengan 90,14\% korban anak perempuan; 70,42\% pada kelompok usia 13-18 tahun; hymen sebagai lokasi tunggal tersering ditemukannya luka yakni 42,19\%; pada korban laki-laki tidak ditemukan luka genital; 42,85\% korban anak laki-laki mengalami luka lecet pada anus; pada 25,35\% korban tidak ditemukan luka baik genital ataupun ekstragenital. Tidak ditemukannya luka ataupun jaringan parut bukan berarti bahwa pada korban tidak terjadi kekerasan.
\end{abstract}

Kata kunci: anak, kekerasan seksual, pola luka. 
Nurul Aida Fathya: Kekerasan Seksual Pada Anak ...

\section{ABSTRACT}

Sexual violence against children case number is like an iceberg phenomenon, because the victims are reluctant to report. Forms of sexual violence against children such as touching or kissing sexual organs, showing pornography, genital exhibit, masturbation, oral sex, anal sex, to intercourse. Sexual violence against children is a criminal offense, and medical evidence of the victim is needed to prove it. Evidence of violence is a wound or scar on the victim's body. Problem in finding signs of violence evidence arises when the victim does not directly report and have a prompt medical examination. This study aims was to determine the injury pattern of sexual violence in children victims. Descriptive method was performed in this study, data were collected from the victim's medical record. The study was conducted at Dr. Hasan Sadikin Bandung hospital, as the main referral hospital in West Java Province. The results of this study there were 71 cases between 2012-2017 period with $90.14 \%$ female victims; $70.42 \%$ in the age group 13-18 years; hymen was the single most frequent location of wounds (42.19\%); in male victims no genital injuries were found; $42.85 \%$ of male victims had anal excoration; no sign of injuriy in both area in $25.35 \%$ of victims. No injuries or scar were found in victim still can not exclude the possibility of violence.

Keywords: children, sexual violence, injury patterns.

\section{PENDAHULUAN}

Berdasarkan undang - undang perlindungan anak (UUPA), yang tergolong anak adalah seseorang di bawah usia 18 tahun, termasuk anak di dalam kandungan. Masalah kekerasan terhadap anak (KtA) merupakan masalah global yang terkait hak asasi manusia, karena dapat timbulnya dampak negatif bagi kesehatan dan juga ancaman masa depan anak. Pemerintah Indonesia telah meratifikasi Konvensi Hak Anak (KHA) Perserikatan Bangsa-bangsa (PBB) melalui Keputusan Presiden No. 36 tahun 1990, yang selanjutnya diperkuat dengan pengesahan Undang-undang No. 23 tahun 2002 tentang Perlindungan Anak. Atas dasar tersebut, negara memiliki kewajiban melakukan perlindungan bagi anak karena mereka merupakan kelompok yang rentan mengalami kekerasan ataupun eksploitasi. ${ }^{1}$ Kekerasan terhadap anak (KtA) berdasarkan Undang-Undang Perlindungan Anak nomor 35 tahun 2014 dapat berupa diskriminasi, dan eksploitasi, baik ekonomi maupun seksual, penelantaran, penganiayaan hingga ketidakadilan. ${ }^{2}$ Bentuk KtA terdiri atas kekerasan seksual, kekerasan fisik, kekerasan psikis hingga penelantaran. ${ }^{3}$ Kekerasan seksual pada 
Nurul Aida Fathya: Kekerasan Seksual Pada Anak ...

anak adalah setiap tindakan seksual yang yang dilakukan terhadap anak tanpa izin, dengan paksaan ataupun pengelabuan (tidak sepenuhnya memahami) dengan tujuan untuk memberikan kepuasan bagi pelaku. Tindakannya dapat berupa menyentuh atau mencium organ seksual, memperlihatkan pornografi, menunjukkan alat kelamin, masturbasi, seks oral, seks anal, hingga persetubuhan. Kekerasan fisik merupakan segala bentuk tindakan yang mengakibatkan rasa sakit, jatuh sakit, atau luka berat. Kekerasan psikis umumnya dilakukan secara verbal oleh pelaku yang mengakibatkan rasa takut, rendah diri, rasa tidak berdaya atau hilangnya kemampuan untuk bertindak, hingga gangguan psikis berat. Penelantaran anak terjadi ketika orang yang bertanggung jawab atasnya tidak melakukan kewajibannya atas hak anak tersebut, antara lain dalam hal pemenuhan gizi, kesehatan, pendidikan hingga kebebasan. ${ }^{4,5,6}$

Menurut World Health Organization (2016), dalam kurun waktu satu tahun tercatat $12 \%$ anak di dunia mengalami kekerasan seksual. Data Komisi Nasional (Komnas) Perlindungan Anak terjadi peningkatan kasus Kekerasan terhadap Anak (KtA) sejak tahun 2010 cenderung meningkat, dengan rincian sebagai berikut: tahun 2010 tercatat 2.467 laporan KtA dimana $42 \%$ merupakan kekerasan seksual; tahun 2011 sebanyak 2.178 kasus dengan 52\% kekerasan seksual; tahun 2012 sebanyak 2.637 kasus dengan 62\% kekerasan seksual; tahun 2013 sebanyak 2.676 kasus dengan 54\% kekerasan seksual; tahun 2014 sebanyak 2.737 kasus dengan $52 \%$ berupa kekerasan seksual; tahun 2015 menjadi 2.898 kasus dengan $59,3 \%$ kekerasan seksual. ${ }^{5}$ Pulau Jawa tercatat sebagai area yang melaporkan kejadian KtA terbanyak. Tahun 2016 Jawa Tengah menempati peringkat pertama, Jawa Timur berada di peringkat kedua dan Jawa Barat di peringkat ketiga. Kekerasan terhadap anak di Jawa Barat tahun 2016 mencatat $62 \%$ kasus KtA adalah kekerasan seksual. ${ }^{5}$ Komisi Perlindungan Anak Indonesia (KPAI) mendapatkan 203 laporan terkait kekerasan seksual dari kota Bandung pada anak selama periode tahun 2011-2016. ${ }^{7}$ Penelitian ini bertujuan untuk mengetahui pola perlukaan korban kekerasan seksual pada anak.

\section{BAHAN DAN METODE}

Penelitian ini adalah penelitian deskriptif, dengan menggunakan sumber data sekunder dari rekam medis korban kekerasan seksual di RSUP dr Hasan Sadikin Bandung periode 2012-2017. Sampel data yang diambil telah memenuhi kriteria inklusi serta eksklusi. Kriteria inklusi penelitian ini adalah data medis 
Nurul Aida Fathya: Kekerasan Seksual Pada Anak ...

korban kekerasan seksual pada anak yang terdiri atas usia, jenis kelamin, pemeriksaan fisik yakni pemeriksaan genital serta ekstragenital. Kriteria eksklusinya ialah data rekam medis pada korban yang tidak disertai Surat Permintaan Visum (SPV).

Variabel penelitian ini terdiri atas jenis kelamin korban, usia korban, lokasi luka, dan jenis luka. Data yang tercatat diolah secara univariat, dan bivariat dengan menggunakan perangkat lunak analisis data. Penelitian ini telah melewati proses kaji etik oleh Komite Etik Penelitian
Kesehatan di RSUP dr. Hasan Sadikin Nomor LB.04.01/A05/EC/305/X/2018.

\section{HASIL DAN PEMBAHASAN}

Penelitian ini mencatat sebanyak 71 kasus kekerasan seksual yang ditangani di Poliklinik anak RSUP dr. Hasan Sadikin Bandung selama periode tahun 2012-2017. Tabel 1 menunjukkan jumlah kasus kekerasan seksual yang tertinggi yaitu pada tahun 2012, dan terendah pada tahun 2015. Kasus kekerasan seksual dari tahun 20122017 di RSHS cenderung mengalami penurunan.

Tabel 1 Jumlah Kasus Berdasarkan Tahun

\begin{tabular}{ccc}
\hline Tahun & Jumlah & Persentase (\%) \\
\hline 2012 & 25 & 35,2 \\
2013 & 14 & 19,7 \\
2014 & 8 & 11,3 \\
2015 & 6 & 8,5 \\
2016 & 10 & 14,1 \\
2017 & 8 & 11,3 \\
\hline Total & 71 & 100 \\
\hline
\end{tabular}

Hasil pada Tabel 1 sesuai dengan data KPAI yang cenderung menunjukkan penurunan. Tahun 2011 terjadi kekerasan seksual terhadap anak sebanyak 216 kasus, tahun 2012 sebanyak 412 kasus, tahun 2013 sebanyak 343 kasus, tahun 2014 sebanyak 656 kasus, tahun 2015 sebanyak 218 kasus, sedangkan pada tahun 2016 meningkat menjadi 120 kasus. $^{7}$

Penurunan tersebut bukan berarti bahwa kejadian kasus kekerasan seksual menurun karena angka yang ditunjukkan hanya berupa jumlah pelaporan, dan tidak menunjukkan jumlah kasus asli. Hal tersebut dapat terjadi akibat jumlah pelaporan yang menurun. Tren pelaporan kejahatan seksual kepada polisi menunjukkan bahwa kurang dari seperlima yang dilaporkan. ${ }^{6}$ Kasus-kasus kekerasan seksual terhadap anak yang tercatat di pelayanan kesehatan merupakan fenomena gunung es, karena belum mencerminkan 
jumlah keseluruhan kasus yang terdapat di masyarakat. Hal tersebut terjadi karena sebagian besar masyarakat masih menganggapnya sebagai aib keluarga, dan ketidaktahuan korban atas tindakan yang ia dapatkan. ${ }^{89}$ Beberapa kasus yang pernah terjadi di Indonesia umumnya menggunakan modus ketidaktahuan atau keluguan korban dengan cara memanipulasi korban sehingga korban tidak tahu bahwa tindakan tersebut merupakan kejahatan atau perilaku yang salah. ${ }^{10}$

Kekerasan terhadap anak dapat dilaporkan kepada Unit Pelayanan Perempuan dan Anak (UPPA) di Kepolisian, Pusat Pelayanan Terpadu Pemberdayaan Perempuan dan Anak (P2TP2A), Pusat Krisis Terpadu (PKT) di rumah sakit, ataupun lembaga swadaya masyarakat pemerhati KtA. ${ }^{11}$ Penanganan KtA dilakukan melalui pendekatan multidisiplin oleh kepolisian, tenaga medis hingga pekerja sosial. Tenaga medis, sesuai kompetensinya menangani masalah kesehatan sekaligus dapat membantu penegakan hukum. ${ }^{4}$ Bentuk pelayanan medikolegal yang dapat dilakukan adalah melakukan pemeriksaan forensik, menerbitkan visum et repertum hingga saksi ahli. Pelayanan korban KtA dapat dilakukan pada fasilitas kesehatan primer ataupun lanjutan. Rumah Sakit Umum
Pusat (RSUP) dr. Hasan Sadikin Bandung adalah rumah sakit rujukan provinsi Jawa Barat yang memiliki pelayanan klinis, dan medikolegal lengkap. Berdasarkan data dari P2TP2A tahun 2012-2017 didapatkan laporan kasus kekerasan seksual yang dirujuk ke P2TP2A terbanyak dari RSUP dr. Hasan Sadikin Bandung.

Penyidik yang berwenang meminta keterangan pemeriksaan medis atas korban KtA sebagai salah satu upaya mendapatkan alat bukti untuk proses peradilan. Visum et repertum memuat data hasil pemeriksaan dokter atas korban, salah satunya gambaran perlukaan. Perlukaan yang terjadi pada korban kekerasan seksual dapat ditemukan pada area genital ataupun bagian tubuh lainnya. Bentuk perlukaan juga bervariasi dari luka lecet, memar, luka terbuka hingga patah tulang. Selain bukti perlukaan pada tubuh, bukti lain adanya persetubuhan terkadang diperlukan pada kasus perkosaan, yakni pemeriksaan sel sperma atau cairan mani. Bukti medis tersebut tidak selamanya dapat ditemukan pada korban karena jarak waktu pemeriksaan oleh dokter yang cukup lama dari waktu kejadian akibat keengganan melapor. Waktu tersebut menyebabkan bukti biologis hilang dan luka mengalami proses penyembuhan, sehingga bukti tindakan kekerasan seksual bisa tidak ditemukan. Hal ini tentunya merugikan 
korban dan menyulitkan penyidik dalam proses pembuktian tindak pidana.

Faktor-faktor yang dapat menyebabkan kasus kekerasan seksual pada anak sering tidak terungkap, salah satunya karena mereka tidak mengerti bahwa dirinya menjadi korban. Ketidaktahuan tersebut menyebabkan korban tidak melapor, dan korban tersebut dapat menjadi pelaku di kemudian hari. ${ }^{9}$ Berdasarkan penelitian Fullu (2014), lebih dari 70\% korban kekerasan akan menjadi pelaku kekerasan di kemudian hari. ${ }^{3}$

Berdasarkan penelitian di Malang, respon anak korban kekerasan seksual setelah kejadian akan diam (41\%), dan menangis (16\%), diikuti dengan bercerita pada orang tua $(17 \%)$, cerita ke teman $(11 \%)$, dan guru $(9 \%) .{ }^{12}$ Karena korban merasa terancam, bahwa akan mengalami konsekuensi yang lebih buruk bila melapor sehingga enggan melapor. Terlebih lagi jika terdapat ikatan emosional dengan pelaku kekerasan, biasanya akan menghindari tindakan hukum yang akan menimpa orang tersebut, seperti orang tua, anggota keluarga atau pacar. ${ }^{13}$ Ketika orang tuanya telah mengetahui kejadian kekerasan seksual, tidak serta merta semuanya akan dilaporkan. Oleh karena malu atau kurang percaya diri dan takut, khususnya kekerasan yang dilakukan oleh anggota keluarga atau orang yang dikenal.
Diperkirakan $30 \%$ pelaku kekerasan seksual terhadap anak adalah anggota keluarga; $60 \%$ merupakan orang yang dikenal misalnya, teman, keluarga, pengasuh, tetangga; sisanya adalah orang asing. 9,14

Pelaku kekerasan yang juga anak menyebabkan orang tua korban enggan melapor karena berpikir bahwa pelaku anak tidak dapat dipidana. Undang-Undang Nomor 11 Tahun 2012 tentang Sistem Peradilan Pidana Anak mendefenisikan anak di bawah umur yang dapat menjalani proses peradilan dan ditempatkan di lembaga pembinaan khusus anak adalah anak yang telah berumur 12 tahun tetapi belum berumur 18 tahun. Undang-Undang ini mengatur tentang keadilan restoratif dan diversi yang dilakukan pada pelaku. Metode ini dimaksudkan agar anak terhindar dari proses peradilan dan diharapkan tidak terjadi stigmatisasi saat kembali ke lingkungan sosial. ${ }^{15}$

\section{Gambaran Korban Kekerasan Seksual \\ Berdasarkan Jenis Kelamin}

Kekerasan seksual dapat terjadi pada anak perempuan maupun laki-laki, namun berdasarkan penelitian ini perempuan lebih banyak mengalami kekerasan seksual. Berdasarkan Tabel 2 tampak bahwa selama periode 2012- 2017, anak perempuan mendominasi sebanyak $90,14 \%$, sedangkan anak laki-laki sebanyak 9,86\%. 
Nurul Aida Fathya: Kekerasan Seksual Pada Anak ...

Tabel 2 Distribusi Jenis Kelamin Berdasarkan Tahun

\begin{tabular}{cccc}
\hline \multirow{2}{*}{ Tahun } & \multicolumn{2}{c}{ Jenis Kelamin } & Jumlah \\
\cline { 2 - 3 } & Laki-laki & Perempuan & \\
\hline 2012 & 2 & 23 & 25 \\
2013 & 1 & 13 & 14 \\
2014 & 0 & 8 & 8 \\
2015 & 2 & 4 & 6 \\
2016 & 0 & 10 & 9 \\
2017 & 2 & 6 & 9 \\
\hline Jumlah & 7 & 64 & 71 \\
\hline
\end{tabular}

Hasil penelitian ini sejalan dengan data yang diungkap World Health Organization (WHO) pada tahun 2016 yakni 1 dari 5 anak perempuan, dan 1 dari 13 anak lakilaki mengalami kekerasan seksual. Prevalensi kekerasan seksual terhadap anak berdasarkan systematic review, dan meta-analysis sebesar $20 \%$ pada anak perempuan dan $8 \%$ pada anak laki-laki. ${ }^{16}$ Menurut data demografis tahun 2008, kekerasan pada anak berdasarkan jenis kelamin dengan kasus tertinggi terdapat pada anak perempuan dengan prevalensi $81,43 \%$, sementara pada anak laki-laki yaitu sebesar 18,57\%. ${ }^{17}$ Kekerasan seksual sangat dipengaruhi oleh paham ketidakadilan gender yang berkembang di masyarakat. Kedudukan perempuan lebih rendah dibandingkan pria sehingga menempatkan perempuan sebagai objek kekerasan seksual. ${ }^{18}$ Perempuan usia 16-19 tahun memiliki risiko 4 kali lebih tinggi MK | Vol. 3 | No. 2 | APRIL 2020 menjadi korban kekerasan seksual dibandingkan populasi umum. ${ }^{14}$

Hasil yang berbeda diungkapkan Survei Kekerasan Terhadap Anak (SKTA) tahun 2006 kasus kekerasan seksual pada anak yang tertinggi terjadi pada anak lakilaki dengan kasus sebesar 900 ribu anak, sedangkan pada anak perempuan yang mengalami kekerasan seksual sebanyak 600 ribu anak. Data Komisi Perlindungan Anak Indonesia (KPAI) tahun 2017 juga menunjukkan bahwa kasus kekerasan seksual 54\% terjadi pada anak laki-laki dan $46 \%$ terjadi pada anak perempuan. ${ }^{7,19} \mathrm{Hal}$ ini juga ditemukan di India, yaitu sebanyak $52,94 \%$ korban adalah anak laki-laki. Perubahan dominasi jenis kelamin laki-laki dapat disebabkan adanya anggapan bahwa korban laki-laki tidak akan kehilangan sesuatu yang berarti seperti keperawanan yang ditandai dengan robeknya selaput dara pada perempuan serta tidak akan 
Nurul Aida Fathya: Kekerasan Seksual Pada Anak ...

menimbulkan kehamilan. Ideologi usia 0-6 tahun, 7-12 tahun, dan 13-18 ketidakadilan gender juga menganggap anak laki-laki lebih unggul, sehingga menyebabkan pengawasan bagi mereka kurang ketat dan mempermudah para pelaku melakukan tindakan kekerasan seksual kepada mereka. ${ }^{18}$

\section{Gambaran Korban Kekerasan Seksual}

Berdasarkan Usia

Kategori usia pada penelitian ini tahun. Berdasarkan Tabel 4.3 kelompok usia yang terbanyak mengalami korban kekerasan seksual adalah usia 13-18 tahun dengan jumlah 50 kasus dengan persentase $70,42 \%$, kemudian diikuti usia 7-12 tahun sebanyak 17 kasus dengan persentase $23,94 \%$ dan yang terakhir usia 0-6 tahun sebanyak 4 kasus dengan persentase dikelompokkan menjadi 3 kelompok, yaitu $5,64 \%$.

Tabel 3 Distribusi Usia Berdasarkan Tahun

\begin{tabular}{ccccc}
\hline Tahun & \multicolumn{4}{c}{ Usia } \\
\cline { 2 - 5 } & 0-6 Tahun & 7-12 Tahun & 13-18 Tahun & Jumlah \\
\hline 2012 & 0 & 7 & 18 & 25 \\
2013 & 1 & 0 & 13 & 14 \\
2014 & 0 & 1 & 7 & 8 \\
2015 & 0 & 4 & 2 & 6 \\
2016 & 2 & 3 & 5 & 10 \\
2017 & 1 & 2 & 5 & 8 \\
\hline Jumlah & 4 & 17 & 50 & 71 \\
\hline
\end{tabular}

Hasil penelitian ini mencatat kelompok usia terbanyak yang mengalami korban kekerasan seksual yakni antara usia 13-18 tahun yakni kelompok remaja awal. Data tersebut sesuai dengan data Sistem Informasi Online Perlindungan Perempuan dan Anak (Simfoni-PPA) pada tahun 2016, yaitu menunjukkan korban kekerasan seksual menurut kelompok umur paling tinggi terjadi pada usia 13-17 tahun yaitu
60\%, sedangkan kelompok usia 6-12 tahun $27 \%$, dan usia 0-5 tahun 13\%. ${ }^{5}$ Serupa dengan temuan di Amerika Serikat dimana $66 \%$ korban berada pada rentang usia 12 17 tahun. $^{14}$ Masa remaja merupakan peralihan antara masa anak-anak ke masa dewasa. Terjadi perubahan pada masa ini yakni kematangan seksual, perkembangan pola identifikasi dan emosi, serta kondisi independensi diri. ${ }^{20,21}$ 
Nurul Aida Fathya: Kekerasan Seksual Pada Anak ...

Remaja sangat rentan terhadap kekerasan seksual karena mereka masih membutuhkan konsep diri sebagai acuan dalam menumbuhkan jati diri. Pengaruh teman sebaya (peer group), prinsip baru dalam memilih teman dan pemimpin serta nilai moral yang dipengaruhi oleh penerimaan kelompok sekitar muncul dalam proses pencarian jati diri. Keingintahuan yang besar serta pengaruh teman sebaya mendorong remaja untuk mencoba pengalaman baru. Kemudahan akses atas tayangan yang menonjolkan aspek pornografi menimbulkan reaksi seksual sehingga mendorong keinginan remaja untuk mencobanya, hal ini bisa membawa remaja ke dunia prostitusi atau bahkan kekerasan seksual. Tercatat dalam bank data KPAI sebanyak 40 anak di kota Bandung dilaporkan terlibat prostitusi. ${ }^{7}$ Dorongan konsumsi alkohol dan obatobatan terlarang juga dapat memicu terjadinya kekerasan seksual. Zat-zat tersebut dapat mempengaruhi kesadaran, pada laki-laki dapat menyebabkan hilangnya kontrol diri dan pada perempuan menjadi sulit untuk melindungi dirinya sendiri dalam menghadapi tindakan kekerasan seksual. ${ }^{20,22}$

Pelaku kekerasan seksual umumnya orang yang memiliki dominasi atas korban, seperti orang dewasa, pacar hingga teman sebaya. Kemampuan pelaku menguasai korban, baik dengan tipu daya maupun ancaman dan kekerasan, menyebabkan kejahatan ini sulit dihindari. Tidak semua pelaku adalah orang dewasa, 23\% dari kekerasan seksual terhadap anak yang dilaporkan dilakukan oleh individu di bawah usia 18 tahun. $^{23}$ Selama periode 2011-2016, KPAI mencatat sebanyak 1498 anak yang terlibat sebagai pelaku kekerasan seksual. ${ }^{7}$

\section{Gambaran Pola Luka Pada Korban Kekerasan Seksual.}

Korban anak yang mengalami kekerasan seksual dapat menderita perlukaan, baik pada area genital ataupun bagian tubuh lainnya. Bentuk perlukaan yang dapat ditemukan antara lain luka lecet, luka memar hingga luka terbuka. Pada penelitian ini luka dikelompokan berdasarkan lokasi yakni area genital dan ekstragenital serta jenis luka yang ditemukan pada korban.

\section{Gambaran Pola Luka Area Genital tahun 2012-2017}

Area genital merupakan lokasi utama yang menjadi perhatian pelaku, karena area genital tersebut dapat memberikan kepuasan seksual bagi pelaku. Pada penelitian meta-analisis tahun 2013 menunjukkan bahwa sekitar 9\% anak perempuan, dan $3 \%$ anak laki-laki 
Nurul Aida Fathya: Kekerasan Seksual Pada Anak ...

mengalami kekerasan seksual (oral, penyebab tidak diketahui; sedangkan pada vagina, atau anal) serta $13 \%$ anak perempuan, dan $6 \%$ anak laki-laki mengalami beberapa bentuk kontak seksual. ${ }^{16}$ Penyebab perlukaan area genital pada anak perempuan prapubertas $(<12$ tahun) yakni: 19\% akibat kecelakaan, 65\% korban anak perempuan masa pubertas (12-18 tahun) seluruhnya diakibatkan oleh kekerasan seksual. $^{24}$ Hasil penelitian gambaran pola luka area genital periode tahun 2012-2017 di RSHS pada penelitian ini dapat dilihat pada Tabel 4.

akibat kekerasan seksual, dan 17\% dengan

Tabel 4 Gambaran Pola Luka Area Genital

\begin{tabular}{cccccc}
\hline Jenis Luka & \multicolumn{5}{c}{ Lokasi Luka } \\
\cline { 2 - 6 } & Labium & Vagina & Hymen & Penis & Skrotum \\
\hline Luka Lecet & 21 & 18 & 1 & 0 & 0 \\
Luka Memar & 0 & 1 & 0 & 0 & 0 \\
Luka Terbuka & 0 & 0 & 46 & 0 & 0 \\
Tidak ada luka & 43 & 45 & 17 & 7 & 7 \\
\hline Jumlah & 64 & 64 & 64 & 7 & 7 \\
\hline
\end{tabular}

Berdasarkan Tabel 4 tampak hymen sebagai lokasi tersering yang mengalami perlukaan pada korban anak perempuan, dengan jenis luka terbuka sebanyak $71,8 \%$. Sejalan dengan temuan penelitian ini, robekan hymen ditemukan sebanyak $85 \%$ pada penelitian Nursasmi tahun 2014. Selanjutnya pada penelitian ini, luka lecet ditemukan pada labium dan vagina masing-masing sebanyak 21 kasus $(32,8 \%)$ dan 18 kasus $(28,1 \%){ }^{25}$

Temuan tersebut dapat dipengaruhi oleh rentang waktu kejadian hingga dilakukannya pemeriksaan, karena luka pada labium dan vagina dapat sembuh dengan sempurna tanpa meninggalkan bekas. Luka lecet pada area genital pada anak perempuan prapubertas dapat menghilang antara 1 hingga 3 hari, sedangkan pada anak perempuan masa pubertas antara 4 hingga 11 hari. Luka memar pada penelitian ini hanya ditemukan pada satu kasus yakni di dinding vagina. Luka memar di area genital pada anak perempuan umumnya menghilang antara 1 hingga 3 hari. ${ }^{26}$ Pada laserasi hymen, tanda-tanda cedera akut berupa edema, perdarahan, pendarahan submukosa, dan hiperemis tepi laserasi hilang dalam 7 sampai 10 hari. Pada wanita dewasa tanda akut tersebut menghilang dalam rentang waktu 24 jam 
Nurul Aida Fathya: Kekerasan Seksual Pada Anak ...

setelah timbulnya luka pada 164 kasus; 48 jam pada 208 kasus dan 48-72 jam pada 31 kasus. $^{27}$

Meskipun tanda akut menghilang dengan segera, proses penyembuhan laserasi pada hymen berbeda dengan laserasi di bagian tubuh lain, dimana luka pada hymen tidak menimbulkan jaringan parut dan dapat tampak sebagai luka terbuka yang irreversibel. ${ }^{28}$ Mc Cann menemukan bahwa pada anak prapubertas, $68 \%$ laserasi menjadi luka terbuka permanen saat penyembuhan dan $87 \%$ pada anak masa pubertas. ${ }^{27}$ Sejalan dengan hal tersebut, Frank dan Anders mengatakan bahwa tidak adanya laserasi pada hymen tidak sepenuhnya menyingkirkan kekerasan seksual, karena laserasi yang tidak terlalu panjang pada permukaan hymen dapat sembuh sepenuhnya. ${ }^{25,29,30}$

Tabel 5 Gambaran Pola Luka Area Genital Pada Korban Perempuan

\begin{tabular}{lccccccc}
\hline Lokasi & & & \multicolumn{7}{c}{ Luka } & & & \\
\hline Labium & + & - & + & - & + & + & - \\
Vagina & + & - & - & + & + & - & - \\
Hymen & + & + & - & + & - & + & - \\
\hline Jumlah & 17 & 27 & 1 & 1 & 1 & 2 & 15 \\
\hline Persentase & 26,56 & 42,19 & 1,56 & 1,56 & 1,56 & 3,13 & 23,44 \\
\hline
\end{tabular}

Penelitian ini mencatat hymen sebagai lokasi tunggal tersering ditemukannya luka, yakni sebesar 42,19\%. Temuan tersebut dapat mengarah kepada luka yang telah menyembuh dan membentuk celah menetap, karena pada umumnya luka yang akut melibatkan bagian area genital lain. Konfigurasi laserasi hymen dapat berlangsung hingga 3 minggu pada prapubertas dan 4 minggu pada pubertas, sedangkan luka pada labium dan vagina menghilang lebih cepat, dan tidak berbekas. $^{24}$ Variasi temuan luka tampak pada Tabel 5, korban yang mengalami perlukaan baru ditunjukkan dengan ditemukannya luka pada ketiga area, atau luka yang melibatkan area labium serta vagina. Berdasarkan proses penyembuhan luka, luka pada hymen saja, dan tidak ditemukan luka pada ketiga area dianggap sebagai kasus yang mengalami penyembuhan atau kasus lama. Sehingga $34,38 \%$ kasus dianggap sebagai kasus yang cukup baru, dan 65,62\% kasus lama.

Hal tersebut erat kaitannya dengan rentang waktu kejadian dengan saat kasus dilaporkan, dan pemeriksaan korban dilakukan. Sebanyak 41\% korban memilih untuk diam, dan tidak melapor sehingga ketika diketahui dirinya mengalami kekerasan seksual, luka yang ada telah mengalami proses penyembuhan. ${ }^{12}$ Akan 
Nurul Aida Fathya: Kekerasan Seksual Pada Anak ...

tetapi analisis gambaran luka terkait rentang waktu tersebut tidak dapat dilakukan karena pada penelitian ini data waktu tersebut tidak tersedia. Sebuah studi pada tahun 2016 melaporkan bahwa hanya 2,2\% (26 dari 1160) anak perempuan yang mengalami kekerasan seksual yang diperiksa secara non-akut didapatkan tanda kekerasan, sedangkan mereka yang diperiksa secara akut, tanda kekerasan ditemukan sebesar $21,4 \%$ (73 dari 340). ${ }^{28}$ Penting bagi tenaga medis yang melakukan pemeriksaan korban anak perempuan tidak hanya mengandalkan kondisi hymen dalam pemeriksaan dan pelaporan kekerasan seksual. ${ }^{31}$ Oleh karena tidak ada standar emas untuk hymen "normal" ataupun pemeriksaan diagnostik atau prediktif bagi hymen, sehingga pemeriksaan menyeluruh tubuh korban adalah tindakan mutlak. Deskripsi seperti "hymen utuh" atau "hymen rusak" harus dihindari, karena utuh bukan berarti bahwa korban tidak mengalami kekerasan. ${ }^{32}$

Gambaran yang berbeda ditunjukkan pada korban anak laki-laki, tidak satupun korban mengalami perlukaan pada area genital baik pada penis maupun skrotum. Hal ini dikarenakan pelaku umumnya adalah laki-laki sehingga kekerasan seksual yang dilakukan dapat berupa seks anal, seks oral atau masturbasi. Berdasarkan hasil penelitian pada anak-

anak di kota Malang menunjukkan terdapat beberapa responden mengalami dicolek, dipegang-pegang, dipeluk dan dicium serta digesek-gesekkan kemaluan pelaku, dan dipaksa nonton video porno. ${ }^{12}$ Tindakantindakan yang dilakukan pada genital anak laki-laki tidak dapat menimbulkan perlukaan, sehingga perlu diperiksa bagian tubuh lainnya seperti anus. Diketahui sebagian besar korban anak laki-laki kasus kekerasan seksual di Indonesia mengalami sodomi. Contoh kasus sodomi yang dilakukan Andi Sobari alias Emon di Sukabumi, yang korbannya mencapai 110 anak dan kasus sodomi oleh penjaga mesjid di Makasar, korbannya puluhan anak berusia antara 9-11 tahun. ${ }^{33}$

\section{Gambaran Pola Luka Area Ekstragenital tahun 2012-2017}

Pemaksaan tindakan seksual oleh pelaku umumnya disertai dengan kekerasan atau ancaman kekerasan. Bukti dari terjadinya kekerasan adalah perlukaan pada korban, baik di area genital ataupun bagian tubuh lainnya. Pada penelitian ini ditemukan sebanyak 11 korban mengalami perlukaan pada area ekstragenital, yang terdiri atas 3 korban laki-laki, dan 8 korban perempuan. Luka ekstragenital yang ditemukan pada penelitian ini bervariasi dari jenis, lokasi serta jumlah pada tiap korban (Tabel 6). 
Nurul Aida Fathya: Kekerasan Seksual Pada Anak ...

Tabel 6 Gambaran Pola Luka Area Ekstragenital pada Tahun 2012-2017

\begin{tabular}{|c|c|c|c|c|c|}
\hline \multirow[b]{2}{*}{ Jenis Luka } & \multicolumn{4}{|c|}{ Lokasi Luka } & \multirow[b]{2}{*}{ Jumlah } \\
\hline & $\begin{array}{l}\text { Kepala dan } \\
\text { Leher }\end{array}$ & $\begin{array}{c}\text { Ekstremitas } \\
\text { Atas }\end{array}$ & $\begin{array}{c}\text { Ekstremitas } \\
\text { Bawah }\end{array}$ & $\begin{array}{l}\text { Batang } \\
\text { Tubuh }\end{array}$ & \\
\hline Luka Lecet & 1 & 0 & 0 & 3 & 4 \\
\hline $\begin{array}{l}\text { Luka } \\
\text { Memar }\end{array}$ & 2 & 3 & 2 & 2 & 9 \\
\hline $\begin{array}{l}\text { Luka } \\
\text { Terbuka }\end{array}$ & 1 & 2 & 1 & 1 & 5 \\
\hline Jumlah & 4 & 5 & 3 & 6 & 18 \\
\hline
\end{tabular}

Lokasi luka tersering yang mengalami kekerasan adalah area batang tubuh dan jenis luka terbanyak adalah luka memar. Sejalan dengan hasil penelitian Sugar dkk, sebanyak $52 \%$ korban perempuan kekerasan seksual yang datang ke unit gawat darurat rumah sakit dalam waktu 72 jam setelah kejadian mengalami memar dan lecet serta tidak ditemukan luka yang serius. ${ }^{33}$ Luka lecet pada penelitian ini seluruhnya terjadi pada anus dan dialami oleh korban anak laki-laki yang dapat disebabkan anal seks atau sodomi. Pada penelitian McCann yang melakukan pengamatan longitudinal luka akut akibat sodomi pada korban anak mencatat regenerasi luka yang dangkal yang dapat pulih dalam 48 hingga 72 jam, karena anak memiliki daya regenerasi yang baik. Laserasi derajat satu dan dua perianal dapat sembuh dalam kurun waktu 1-2 minggu dan bisa tidak ditemukan adanya jaringan parut. Laserasi derajat tiga yang melibatkan sfingter ani yang membutuhkan tatalaksana operatif membutuhkan waktu penyembuhan hingga 1 bulan. ${ }^{34}$

Kekerasan seksual pada anus yang terjadi beberapa kali dapat menyebabkan terbentuknya jaringan parut hingga kerusakan sfingter ani. ${ }^{23}$ Jaringan parut pada area anus tampak sebagai penebalan dari kulit di luar dan di perianal dapat juga timbul akibat dari pruritus yang digaruk. ${ }^{6}$ Terdapat literatur yang mengatakan bahwa jaringan parut berbentuk baji (wedges shape) pada perianal menunjukan adanya trauma, dan bentuk kipas (fan shape) merujuk kepada kekerasan berulang. Penelitian McCann (1993) menunjukan hal yang berbeda yakni jaringan parut dari satu kali trauma tampak seperti garis yang sempit. Jaringan parut bentuk baji dan kipas pada garis tengah anus juga ditemukan pada $26 \%$ anak normal, yang dikenal sebagai diastasis ani. ${ }^{35}$

Pada empat $(57,14 \%)$ korban anak laki-laki pada penelitian ini tidak ditemukan luka-luka baik genital ataupun 
Nurul Aida Fathya: Kekerasan Seksual Pada Anak ...

ekstragenital. Tidak ditemukannya tanda perlukaan tidak berarti bahwa pada korban tidak terjadi kekerasan. Hal ini dipengaruhi faktor waktu, dengan berlalunya waktu, luka mengalami proses penyembuhan, tidak meninggalkan parut, terlebih lagi jika kekerasan seksual terjadi satu kali. ${ }^{34,36}$ Sebaiknya, pemeriksaan dilakukan sesegera mungkin setelah kejadian, tetapi kondisi ini tidak selalu dapat terjadi karena pelaporan tertunda oleh karena korban merasa takut. ${ }^{6}$

Luka-luka yang terjadi pada daerah kepala dan leher, ekstremitas atas, serta ekstremitas bawah umumnya terjadi akibat pemaksaan pelaku karena perlawanan dari korban. Luka pada area leher juga dapat terjadi akibat kissing bite oleh pelaku karena dapat menimbulkan rangsangan seksual bagi dirinya. Penelitian Mun'im menemukan luka terutama pada daerah leher didapatkan sebanyak 21\%, 10\% luka hanya di area genital, dan 7\% mendapat luka area genital dan ekstragenital. ${ }^{37}$ Berbeda dengan penelitian ini yang sebagian besar $(59,15 \%)$ korban mengalami perlukaan pada area genital (Tabel 7).

Tabel 7 Gambaran pola luka area genital dan ekstragenital

\begin{tabular}{|c|c|c|c|c|c|c|}
\hline \multirow[t]{2}{*}{ Genital } & Ter & luka & Tid & $\begin{array}{l}\text { genita } \\
\text { luka }\end{array}$ & & lah \\
\hline & $\mathbf{n}$ & $\%$ & $\mathrm{n}$ & $\%$ & $\mathbf{n}$ & $\%$ \\
\hline Terdapat luka & 7 & 9,86 & 42 & 59,15 & 49 & 69,01 \\
\hline Tidak ada luka & 4 & 5,64 & 18 & 25,35 & 22 & 30,99 \\
\hline Jumlah & 11 & 15,5 & 60 & 84,5 & 71 & 100 \\
\hline
\end{tabular}

Tidak ditemukannya luka pada ekstragenital dan hanya luka genital dapat terjadi karena merupakan kasus lama dan luka pada area genital masih tampak tetapi di ekstragenital sudah mengalami penyembuhan. Seperti luka laserasi di hymen yang bersifat irreversibel. Agar tidak terjadi salah arti, tenaga medis harus menjelaskan temuan spesifik menggunakan standar internasional dan terminologi morfologis yang jelas, yakni jenis perlukaan, ciri luka serta lokasinya. ${ }^{32}$

\section{KESIMPULAN}

Korban dengan perlukaan pada labium, dan vagina serta area ekstragenital dapat menunjukkan bahwa kejadian kekerasan cukup baru. Persentase temuan kekerasan yang kecil menunjukkan adanya keterlambatan pemeriksaan oleh dokter yang umumnya diakibatkan pelaporan yang terlambat. Tidak adanya luka ataupun jaringan parut tidak dapat menyingkirkan kejadian kekerasan yang diakui korban, sehingga riwayat medis dan seksual yang 
Nurul Aida Fathya: Kekerasan Seksual Pada Anak ...

relevan yang mungkin memengaruhi temuan fisik apa pun selama pemeriksaan perlu digali dengan baik. Deskripsi luka dan pencatatan yang baik serta akurat dapat membantu pembuktian tindak pidana kekerasan seksual terhadap anak, karena dengan kurangnya bukti medis dapat menghambat proses perkara pidana, dan

\section{DAFTAR PUSTAKA}

1. The United Nations Children's Fund. Convention On The Rights Of The Child. 1989. Available At: Https://Www.Unicef.Org/Sites/Default /Files/2019-04/Un-Convention-RightsChild-Text.Pdf (Diakses Tanggal 31 Januari 2020)

2. Undang-Undang Republik Indonesia No.35 Tahun 2014 tentang perubahan undang-undang perlindungan anak nomor 23 tahun 2002.

3. Suharto E. Kekerasan terhadap anak respon pekerjaan sosial. Kawistara. 2015;5(1):1-98.

4. Direktorat Jenderal Bina Kesehatan Masyarakat Kementerian Kesehatan Republik Indonesia. Pedoman Pengembangan Puskesmas Mampu Tatalaksana Kasus Kekerasan Terhadap Perempuan Dan Anak. 2009.

5. Kementerian Pemberdayaan Perempuan dan Perlindungan Anak. pelaku menjadi sulit untuk diadili. Penelitian ini memiliki kelemahan karena tidak tersedianya data rentang waktu pemeriksaan dengan waktu kejadian kekerasan seksual, sehingga tidak dapat dilakukan analisis perubahan luka pada korban.

Mengakhiri Kekerasan Terhadap Perempuan dan Anak di Indonesia. Jakarta: Gramedia. 2017. Hal 69-85.

6. Shepherd R. Simpson's forensic medicine $12^{\text {th }}$ edition. London: Arnold Publisher. 2003. Hal 128-132

7. Komisi Perlindungan Anak Indonesia. Data Kasus Perlindungan Anak Berdasarkan Lokasi Pengaduan Dan Pemantauan Media Se-Indonesia Tahun 2011-2016.

http://bankdata.kpai.go.id/tabulasidata/data-kasus-seindonesia/ datakasus-perlindungan-anak-berdasarkanlokasi-pengaduan-dan-pemantauanmedia-se-indonesia-tahun-20112016\#bandung. (diakses tanggal 06 juni 2018)

8. National Sex Offender Public Website (Nsopw). Raising awareness about sexual abuse. The US Department Of Justice. 2019. Available At: 
Nurul Aida Fathya: Kekerasan Seksual Pada Anak ...

Https://Https//Www.Nsopw.Gov/En-

Us/Education/Factsstatistics\#Prepetrato

rs (Diakses Tanggal 31 Januari 2020)

9. Mubiar A, Ipah S, Gustiana AD. Efektivitas konseling kognitif-perilaku dengan teknik latihan asertif untuk mengatasi tindakan kekerasan pada anak. Universitas Pendidikan Indonesia. 2016;11 (2): 121-29.

10. Probosiswi R dan Bahransyaf D. Masalah dan perlindungan terhadap anak. Kementerian Sosial RI 2015;1(1):29-40.

11. Peraturan Menteri Negara Pemberdayaan Perempuan Dan Perlindungan Anak Republik Indonesia Nomor 2 Tahun 2011 Pedoman Penanganan Anak Korban Kekerasan. 2011

12. Andini T.M, Sulistyowati T, Alifatin A, Dkk. identifikasi kejadian kekerasan pada anak di Kota Malang. Jurnal Perempuan dan Anak (Jpa). 2019;2(1):13-28

13. Reilly M, Williams B H. Teens and sexual abuse. Journal Of American Medical Association. 2015;314(11):1192

14. Rape, Abuse and incest national network (Rainn). Statistics. Available At:Https://Www.Rainn.Org/Statistics (Diakses Tanggal 31 Januari 2020)
15. Undang-Undang Republik Indonesia Nomor 11 Tahun 2012 Tentang Sistem Peradilan Pidana Anak. 2012

16. World Health Organization. Responding To Children And Adolescents Who Have Been Sexually Abused: Who Clinical Guidelines. 2017

17. Sisca H, Moningka C. Resiliensi perempuan dewasa muda yang pernah mengalami kekerasan seksual di masa kanak-kanak. Jurnal Psikologi. 2008;2(1):61-9.

18. Subramaniyan Vks, Reddy P, Chandra G, Rao C, Rao Tss. Silence of male child sexual abuse in India: Qualitative Analysis Of Barriers For Seeking Psychiatric Help In A Multidisciplinary Unit In A General Hospital. Indian Journal Of Psychiatry. 2017;59(2):202-207. Available at: Https://Www.Ncbi.Nlm.Nih.Gov/Pmc/ Articles/ Pmc 5547862/ (Diakses Tanggal 31 Januari 2020)

19. Ryan C. W. Hall, MD, Richard C.W. Hall, MD P. A profile pedophilia defin charact offenders, recodovosm, treat outcomes, forensic issues. Journal Medical. 2016;82(4):457-71.

20. Kurniasari A. Analisis faktor risiko dikalangan anak yang menjadi korban eksploitasi seksual di Kota Surabaya. J Sosio Konsepsia 2016; 05: 113-25. 
Nurul Aida Fathya: Kekerasan Seksual Pada Anak ...

21. Tumade M Angelina. Aspek pidana kekerasan seksual terhadap orang yang belum dewasa. Departemen Fakultas Hukum Samratulangi; 2015. http://download.portalgaruda.org/articl e.php?article $=316033 \&$ val $=1030 \&$ title $=$ ASPEK\%20PIDANA\%20KEKERAS AN\%20SEKSUAL\%20TERHADAP\% 20ORANG\%20YANG\%20BELUM\% 20DEWASA. (Diakses tanggal 27 Januari 2019).

22. World Health Organization. Responding to Children and Adolescents who have been Sexually Abused. WHO. 2017.

23. National Sex Offender Public Website (Nsopw). Raising awareness about sexual abuse. The Us Department Of Justice. 2019. Available At: Https://Https//Www.Nsopw.Gov/EnUs/Education/Factsstatistics\#Prepetrato rs (Diakses Tanggal 31 Januari 2020)

24. McCann J, Miyamoto S, Boyle C and Rogers K. healing of hymenal injuries in prepubertal and adolescent girls: a descriptive study 2007;119; e1094-1106. Available at: http://pediatrics.aappublications.org/co ntent/119/5 /e1094. full. html (Diakses Tanggal 31 Januari 2020)

25. Nursasmi AT, Susanti R, Bachtiar H. Perbedaan perlukaan genitalia perempuan berdasarkan posisi persetubuhan di luar perkawinan di RSUP Dr. M. Djamil Padang Tahun 2010-2012. J kesehatan Andalas 2014; 03: $102-5$.

26. Hanson RK. The psychological impact of sexual assault on women and children. York University Journal 1990;3(2):187-232.

27. Anderson SL, Parker BJ. Changes in genital injury patterns over time in women after consensual intercourse.J Forensic Leg Med 2008; 15: 306-11.

28. Joyce A. Adams J A,Farst K J, Kellogg $\mathrm{N}$ D. interpretation of medical findings in suspected child sexual abuse: an update for 2018. Journal of Pediatric and Adolescent Gynecology. 2018;31: 225-231.

29. American Medical Association. Differences in hymenal morphology between adolescent girls with a history of consensual sexual intercourse. Archives of Pediatrics Medicine; 2004.

30. Srivinas SM. Skin lesions simulating child abuse. Journal of University Birmingham. 2018; 19(3): 187-93.

31. Departement of reproductive health and research world health organization. Strengthening the medicolegal response to sexual violence. Swiss: 2014.

32. Mishori R, Ferdowsian H, Naimer K, Volpellier M, McHale T. The little 
Nurul Aida Fathya: Kekerasan Seksual Pada Anak ...

tissue that couldn't - dispelling myths about the Hymen's role in determining sexual history and assault. Reproductive Health. 2019;16:74.

33. Ningsih E S B. Hennyati S. Kekerasan seksual pada anak di kabupaten karawang. Midwife Journal. 2018;4:2.56-65.

34. Saukko P. Knights B. Knights.Forensic pathology $4^{\text {th }}$ Edition. New York: CRC Press.2016. Hal 431-434

35. McCann J. Voris J. Perianal injuries resulting from sexual abuse: a longitudinal study. Pediatrics. 1993;91:3. 390-397
36. Purwaningrum J, Soekry E. Analisa pidana sodomi pada anak. Perhimpunan Dokter Forensik Indonesia. 2017. http://fk.unri.ac.id/wpcontent/uploads/2017/08/27.-JULIPURWANINGRUM-FIX.pdf (Diakses tanggal 28 Januari 2019).

37. Idris AM, Tjiptomarnoto AL. Ilmu kedokteran forensik dalam proses penyidikan. Jakarta: CV Sagung Seto; 2011. hal 113-23. 